\title{
Open defecation free: where do we need to focus?
}

\author{
Ramesh Adhikari' ${ }^{1}$, Sudha Ghimire ${ }^{2}$ \\ ${ }^{1}$ Mahendra Ratna Campus, Tribhuvan University, Kathmandu, Nepal \\ ${ }^{2}$ Graduate School of Education, Tribhuvan University, Kirtipur, Nepal
}

Received:

1 December 2018

Revised:

20 August 2019

Accepted:

11 September 2019

${ }^{*}$ Corresponding author

Ramesh Adhikari

rameshipsr@gmail.com

\begin{abstract}
Background

Despite major national and international efforts, many households in Nepal (as in other low-income and middle-income countries) still lack toilets. This paper assesses various determinants that act as main contributing factors because of which households in Nepal still do not have toilets.
\end{abstract}

\section{Methods}

Data from the Nepal Demographic and Health Survey (NDHS) 2016 was used for this study. Bivariate analysis was done to assess the association between dependent variables (toilet status- having and not having toilets in the household) and independent variables (demographic, socio-economic and geographical characteristics) using Chi-square test. Then, a multivariate logistic regression model was used to assess significant predictors for a household not having a toilet after controlling other variables.

\section{Results}

Out of the total number of sampled households (11040), nearly a fifth (18\%) belonged to province no. 2, where nearly half of the households (49\%) did not have toilet facilities. Similarly, households in rural areas were found to be less likely to have toilets than households in urban areas ( $\mathrm{aOR}=1.56, \mathrm{CI} 1.35-1.80$ ). In the Terai, households were almost ten times as likely not to have toilets (aOR=9.65, CI6.56-14.19) as compared to households in the mountain region. Furthermore, there is a strong positive association between households with toilets and their economic status. Poorest ( $\mathrm{aOR}=15.19$, CI11.26-20.47), poorer (aOR=8.75, CI6.89-11.11) and middle-income ( $\mathrm{aOR}=5.12$, CI4.15-6.32) households were less likely to have a toilet than richer or richest households.

\section{Conclusions}

Despite some real achievements and progress in Open Defecation Free (ODF) status, Nepal still has a large number of residences without a toilet. Thus, it is crucial to address all the multifaceted factors such as geographical, provincial and economic when considering sustainable ODF programming.

Keywords: Open Defecation Free (ODF), Sanitation, Nepal, Sustainable Development

Tweetable Abstract: Despite some progress in ODF status, Nepal still has residences without a toilet. So the question is where we need to focus.

\section{Background}

If not managed properly, human faeces can cause various kinds of communicable diseases, from viral and bacterial to protozoan. Hygienic and proper use of toilets is a step forward in managing those diseases. The burden of these faeco-oral diseases is high in low and middle-income countries (LMICs) like Nepal, where not having access to toilets is considered a major determinant of public health problems, including risk of diarrheal and other water borne diseases [1]. Toilets are a primary barrier to faeco-oral disease transmission and better sanitation practice is recognized as an important parameter for a healthy, dignified and developed society. The goal of achieving adequate and equitable sanitation has been agreed globally, and eliminating Open Defecation (OD) world wide by 2030 is included in the Sustainable Development Goal number six [2]. Despite this, 2.4 billion people around the world lack adequate sanitation and practice open defecation $[3,4]$.

In the context of Nepal, the Constitution has declared access to safe water and sanitation a fundamental right of citizens [5]. The government of Nepal has set a target for universal access to improved sanitation by 2017, for better hygiene, health and environment [6]. Unfortunately, we still have houses, offices and schools without toilets or with poor utilization of toilets. A sanitation promotion program was started in Nepal in the early $1990 \mathrm{~s}$ as an integral component of water supply projects and since then it has been a working area for governmental and non-governmental agencies. Till date some innovative ideas and concepts have been adopted for sanitation and hygiene, for instance, Open Defecation Free communities, Community Led Total Sanitation [7], school led total sanitation [8], basic sanitation package, school sanitation and hygiene education, national sanitation week [9], global handwash- 
ing day, world toilet day, Nepal water sanitation and hygiene [6] and much more. All of these have helped achieve the current status where 85 percent of household have toilets (as at the end of 2018) [10]. Households without toilets have various common factors, ranging from socio-culture norms [11] to economic status [12] of the people, creating further challenges for the effectiveness of these programs. Furthermore, despite huge government efforts, a lack of public awareness, human resource constraints, and a lack of proper planning act as obstacles to achieving total sanitation $[6,13]$. In order to meet government targets, there was national trend for declaring Open Defecation Free (ODF) areas, but some evidence shows inability of those areas to maintain their ODF status; for example, village development committees previously declared ODF were found to be unable to maintain minimum requirements of an ODF area afterwards [14]. Furthermore, although people have constructed toilets with the help of subsidy provided by the government, they do not always use them because of entrenched ethnic and cultural taboos [15], traditional beliefs [16] etc. For example, in some cultures there is a belief that an in-law and a daughter-inlaw cannot use the same toilet. There still are communities where menstruating women cannot use the toilet because of a belief that they are untouchable during their days of menstruation. Similarly, unmanaged urbanization resulting in tightly clustered settlements, lack of space for building toilets, lack of technical support, and poor behavioral attitudes are major challenges for ODF sustainability. The poor, disadvantaged and high-risk groups are outside of the sanitation mainstream, undermining equity, ownership and participation. This acts as a further obstacle to full toilet coverage. Though there has been a shift of approach from the conventional awareness raising approach towards a behavior change approach in pursuit of sustainable ODF, there still is lots of room for improvement, from the individual to the policy making level.

\section{Methodology}

\section{Study Area and Data collection}

This paper uses data from the Nepal Demographic and Health Survey, 2016, a nationally representative sample survey. The primary objective of the $2016 \mathrm{NDHS}$ is to provide up-to-date estimates of basic demographic and health indicators. The information collected through the 2016 NDHS is intended to assist policy makers and program managers in the Ministry of Health and other organizations in designing and evaluating programs and strategies for improving the health of the country's population. The study protocol was approved by the Nepal Health Research Council and the ICF Macro Institutional Review Board in Calverton, Maryland, USA. The sampling frame used for the 2016 NDHS is an updated version of the frame from the 2011 National Population and Housing Census (NPHC). The 2016 NDHS sample was stratified and selected in two stages in rural areas and three stages in urban areas. In rural areas, wards were selected as primary sampling units (PSU), and households were selected from the sample PSUs. In urban areas, wards were selected as PSUs, one enumeration area (EA) was selected from each PSU, and then households were selected from the sample EAs. A total of 11,040 household were sampled. Data was collected via interview, yielding a response rate of $99 \%$. The NDHS report details the methodology used in the survey $(\mathrm{MoH}, 2017)$.

\section{Study Variables}

Dependent variables: toilet status is categorized into two different categories; ' 1 ' for having toilets and ' 0 ' for not having toilets.

Independent variables: demographic, socio-economic, and geographical characteristics (As listed in Table 1)

\section{Statistical Analysis}

The weighted percentage was calculated. Association between dependent variable (toilet status-having and not having a toilet in the household) of households and independent variables (demographic, socio-economic, and geographical characteristics) was assessed via bivariate analysis using a Chi-square test. Then, a multivariate logistic regression model was used to assess significant predicators for not having a toilet in the household, after controlling for other variables. All the variables were included in the same model and analyzed. Multi-co-linearity between the variables was assessed before analyzing in logistic analysis. The acceptance level of co-linearity was below 0.7 . The analysis found that two variables 'Development regions' and 'Province' were highly correlated ( $\mathrm{r}=0.97)$. Therefore, 'Development regions' was removed from the logistic regression model. The Statistical Package for Social Science (SPSS 20.0 for Windows) software was used to analyze the data.

\section{Results}

Out of the total sampled households $(11,040) 85 \%$ of them had toilet in their household (Figure 1). Nearly fourth of the respondents belonged to province number 3, more than three-fifths (61\%), were urban residents. Respondents were almost equally distributed among different wealth quintiles (Table 1).

Table 1 Characteristics of sampled household

\begin{tabular}{lll}
\hline Characteristics & \% & N \\
\hline Province & 18.2 & 2004 \\
Province 1 & 18.2 & 2014 \\
Province 2 & 22.8 & 2521 \\
Province 3 & 10.6 & 1173 \\
Province 4 & 16.2 & 1793 \\
Province 5 & 5.6 & 619 \\
Province 6 & 8.3 & 916 \\
Province 7 & & \\
Place of residence & 61.4 & 6781 \\
Urban & 38.6 & 4259 \\
Rural & & \\
Development region & 23.5 & 2590 \\
Eastern & 35.8 & 3949 \\
Central & 20.3 & 2245 \\
Western & 12.1 & 1339 \\
Mid-western & 8.3 & 915 \\
Far-western & & \\
Ecological zones & 7.1 & 781 \\
Mountain & 46.5 & 5134 \\
Hill & & \\
& &
\end{tabular}


Terai

46.4

5125

\section{Wealth Index}

Poorest

20.2

2234

Poorer

20.2

2225

Middle

18.7

2065

Richer

20.3

2240

Richest

20.6

2276

Place for hand washing

Hand washing station was

2104

mobile

Hand washing station is fixed

80.9

8936

Presence of water at hand washing place

Water not available

22.7

2503

Water is available

77.3

8508

Time to get to water source

On premises

$68.9 \quad 7608$

Upto 15 minutes

22.9

2529

16-30 minutes

6.2

685

More than half an hour

2.0

217

Distance to reach nearest health facility

Less than 30 minutes

49.3

5446

30-59 minutes

25.9

22.2

2855

1-2 hours

2.6

2452

More than 2 hours

Sex of head of Household

Male

68.7

7581

Female

31.3

3459

Age of Household head

Less than 25 years

5.7

625

25-34 years

20.3

2240

35-49 years

33.8

3732

50 or more

40.2

4442

Has radio

No

70.7

7811

Yes

29.3

3229

\section{Has television}

No

$\begin{array}{ll}48.4 & 5346 \\ 51.6 & 5694\end{array}$

Yes

51.6

10541

Protected source

95.5

499

Unprotected source

4.5

Any household member migrated in past 10 years

\begin{tabular}{lll} 
No & 53.5 & 5911 \\
Yes & 46.5 & 5129 \\
Total & 100.0 & 11040 \\
\hline
\end{tabular}

Toilet Facility at Household

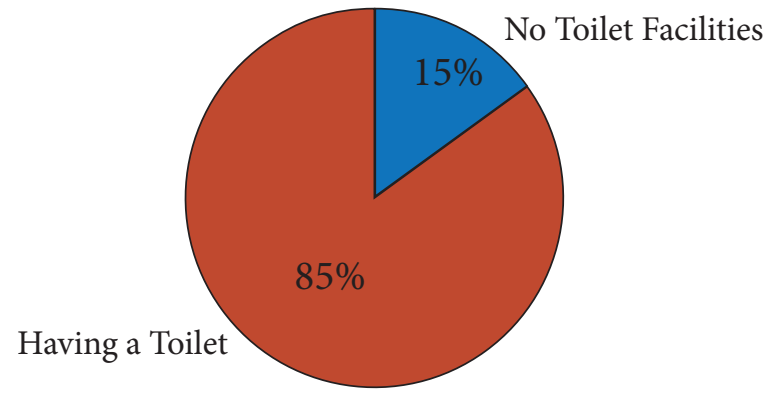

Having a Toilet $\_$No Toilet Facilities

Figure 1: Toilet Facilities at household

Table 2 shows toilet distribution according to the household characteristics. Nearly half (49\%) of households in province number 2 had no toilet facility. The proportion of households without toilet was signficantly higher in rural areas (21\%) and Terai region (27\%) as compared to their respective counterparts. Almost a quarter of respondents belonging to middle and poorer wealth index had no toilet facility in the household. (Table2).

Table 2 Toilet facility according to household characteristics

\begin{tabular}{|c|c|c|c|}
\hline \multirow[t]{2}{*}{ Characteristics } & \multicolumn{2}{|c|}{ Toilet Facility } & \multirow{2}{*}{$\begin{array}{l}\text { Total } \\
\mathbf{N}\end{array}$} \\
\hline & $\begin{array}{l}\text { Having toilet } \\
\text { facility }\end{array}$ & $\begin{array}{l}\text { No Toilet } \\
\text { facility }\end{array}$ & \\
\hline \multicolumn{4}{|l|}{ Province ${ }^{* * *}$} \\
\hline Province 1 & 90.0 & 10.0 & 2004 \\
\hline Province 2 & 51.0 & 49.0 & 2014 \\
\hline Province 3 & 94.8 & 5.2 & 2521 \\
\hline Province 4 & 96.9 & 3.1 & 1173 \\
\hline Province 5 & 89.3 & 10.7 & 1793 \\
\hline Province 6 & 95.6 & 4.4 & 619 \\
\hline Province 7 & 94.7 & 5.3 & 915 \\
\hline \multicolumn{4}{|c|}{ Place of residence ${ }^{* * *}$} \\
\hline Urban & 89.2 & 10.8 & 6781 \\
\hline Rural & 79.1 & 20.9 & 4259 \\
\hline \multicolumn{4}{|c|}{ Development region ${ }^{* * *}$} \\
\hline Eastern & 83.0 & 17.0 & 2590 \\
\hline Central & 77.8 & 22.2 & 3949 \\
\hline Western & 92.0 & 8.0 & 2245 \\
\hline Mid-western & 94.3 & 5.7 & 1339 \\
\hline Far-western & 94.7 & 5.3 & 915 \\
\hline \multicolumn{4}{|c|}{ Ecological zones ${ }^{\star \star *}$} \\
\hline Mountain & 94.2 & 5.8 & 781 \\
\hline Hill & 96.1 & 3.9 & 5134 \\
\hline Terai & 73.1 & 26.9 & 5125 \\
\hline \multicolumn{4}{|l|}{ Wealth Index ${ }^{* * *}$} \\
\hline Poorest & 84.2 & 15.8 & 2234 \\
\hline Poorer & 75.4 & 24.6 & 2225 \\
\hline
\end{tabular}


Adhikari et al. (2020)

$\begin{array}{lccc}\text { Middle } & 73.4 & 26.6 & 2065 \\ \text { Richer } & 92.5 & 7.5 & 2240 \\ \begin{array}{l}\text { Richest } \\ \text { Place for hand washing }\end{array} & 99.8 & 0.2 & 2276 \\ \begin{array}{l}\text { Place for hand washing } \\ \text { was mobile }\end{array} & 69.0 & 31.0 & 2104 \\ \begin{array}{l}\text { Place for hand washing } \\ \text { Pla }\end{array} & 89.2 & 10.8 & 8936\end{array}$

station is fixed

Presence of water at hand washing place ${ }^{\star \star *}$

Water not available

$71.0 \quad 29.0$

2503

Water is available

89.5

10.5

8508

Time to get to water source ${ }^{\star * *}$

$\begin{array}{llll}\text { On premises } & 86.8 & 13.2 & 7608 \\ \text { Up to } 15 \text { minutes } & 79.5 & 20.5 & 2529 \\ \text { 16-30 minutes } & 89.3 & 10.7 & 685 \\ \text { More than half an hour } & 86.6 & 13.4 & 217\end{array}$

Distance to reach nearest health facility ${ }^{* * *}$

$\begin{array}{llll}\text { Less than 30 minutes } & 84.7 & 15.3 & 5446 \\ \text { 30-59 minutes } & 84.4 & 15.6 & 2855 \\ \text { 1-2 hours } & 86.8 & 13.2 & 2452 \\ \text { More than 2 hours } & 92.9 & 7.1 & 286\end{array}$

Sex of head of Household (ns)

Male 85.2

$85.2 \quad 14.8 \quad 7581$

Female $\quad 85.7$

$14.3 \quad 3459$

Age of Household head (ns)

\begin{tabular}{|c|c|c|c|}
\hline Less than 25 years & 86.0 & 14.0 & 625 \\
\hline 25-34 years & 84.7 & 15.3 & 2240 \\
\hline $35-49$ years & 86.0 & 14.0 & 3732 \\
\hline 50 or more & 84.9 & 15.1 & 4442 \\
\hline \multicolumn{4}{|l|}{ Has radio $* * *$} \\
\hline No & 82.2 & 17.8 & 7811 \\
\hline Yes & 92.8 & 7.2 & 3229 \\
\hline \multicolumn{4}{|l|}{ Has television ${ }^{\star * \star}$} \\
\hline No & 78.1 & 21.9 & 5346 \\
\hline Yes & 92.1 & 7.9 & 5694 \\
\hline
\end{tabular}

Source of drinking water *

$\begin{array}{llll}\text { Protected source } & 85.5 & 14.5 & 10541\end{array}$

$\begin{array}{llll}\text { Unprotected source } & 81.8 & 18.2 & 499\end{array}$

Any household member migrated in past 10 years *

$\begin{array}{lccc}\text { No } & 86.1 & 13.9 & 5911 \\ \text { Yes } & 84.4 & 15.6 & 5129 \\ \text { Total } & 85.3 & 14.7 & 11040 \\ \text { Note }^{* * *} \text { Significant at } \mathrm{p}<0.001 ;{ }^{* *}=\mathrm{p}<0.01 \text { and }^{*}=\mathrm{p}<0.05, \text { ns=not significant }\end{array}$

Table 3 reveals the results of a Multi variate analysis and shows that households from province 2 are five times ( $\mathrm{aOR}=5.32, \mathrm{CI} 4.32-6.56$ ) more likely not to have toilets as compared to province 1, keeping all other variables constant in the logistic model. Similarly, as compared to urban areas, the number of households from rural area without toilets was nearly two times more ( $\mathrm{aOR}=1.56, \mathrm{CI} 1.35-1.80)$. Based on ecological zone, households in the Terai region are almost ten times $(\mathrm{aOR}=9.65, \mathrm{CI} 6.56-14.19)$ more likely not to have a toilet in their houses as compared to the mountain region. Furthermore, there is a strong association of toilets with economic status of households, where poorest income households are fifteen times $(\mathrm{aOR}=15.19, \mathrm{CI} 11.26=20.47)$, more likely not to have a toilet than the richer / richest households. (Table3).

Table 3: Adjusted odds ratio (aOR) and $95 \%$ confidence interval (CI) from logistic regression model of not having toilet by Geographic, socio-economic characteristics of household

\begin{tabular}{llll}
\hline \multirow{2}{*}{ Selected predicators } & \multirow{2}{*}{ aOR } & \multicolumn{2}{c}{$95 \% \mathrm{CI}$} \\
\cline { 3 - 3 } & & Lower & Upper \\
\hline
\end{tabular}

\section{Province}

Province 1(reference) 1.00

Province $2 \quad 5.32^{* * *} \quad 4.32 \quad 6.56$

$\begin{array}{llll}\text { Province } 3 & 1.22 & 0.93 & 1.59\end{array}$

$\begin{array}{llll}\text { Province } 4 & 0.429^{* * *} & 0.28 & 0.64\end{array}$

$\begin{array}{llll}\text { Province } 5 & 0.81 & 0.64 & 1.02\end{array}$

$\begin{array}{llll}\text { Province } 6 & 0.40^{* * *} & 0.26 & 0.63\end{array}$

$\begin{array}{llll}\text { Province } 7 & 0.35^{\star * *} & 0.25 & 0.49\end{array}$

Place of residence

Urban (reference) $\quad 1.00$

$\begin{array}{llll}\text { Rural } & 1.56^{\star * *} & 1.35 & 1.80\end{array}$

Ecological zones

Mountain (reference) 1.00

$\begin{array}{llll}\text { Hill } & 1.15 & 0.81 & 1.64\end{array}$

$\begin{array}{llll}\text { Terai } & 9.65^{* * *} & 6.56 & 14.19\end{array}$

Wealth Index

$\begin{array}{llll}\text { Poorest } & 15.19^{* * *} & 11.26 & 20.47\end{array}$

$\begin{array}{llll}\text { Poorer } & 8.75^{* * *} & 6.89 & 11.11\end{array}$

$\begin{array}{llll}\text { Middle } & 5.12^{\star * *} & 4.15 & 6.32\end{array}$

Richer/Richest (ref- 1.00 erence)

Place for hand washing

Place for hand wash- $1.54^{* * *} \quad 1.22 \quad 1.93$

ing was mobile

Place for hand wash- 1.00

ing station is fixed

(reference)

Presence of water at hand washing place

$\begin{array}{llll}\text { Water not available } & 1.40^{\star * *} & 1.11 & 1.77\end{array}$

Water is available $\quad 1.00$

(reference)

Time to get to water source (minutes) 
On premises (refer- $\quad 1.00$

ence)

$\begin{array}{llll}\text { Upto } 15 \text { minutes } & 1.14 & 0.96 & 1.36 \\ \text { 16-30 minutes } & 1.16 & 0.82 & 1.64 \\ \text { More than half an } & 1.20 & 0.72 & 2.01\end{array}$

hour

Distance to reach nearest health facility

Less than 30 minutes 1.00

(reference)

30-59 minutes

$1.25^{\star}$

1.05

1.48

1-2 hours

$\begin{array}{ll}1.20 & 0.99\end{array}$

1.46

More than 2 hours

0.84

0.48

1.44

Sex of head of Household

Male (reference) $\quad 1.00$

Female $\quad 0.97$

Age of Household head

Less than 25 years

$1.43^{*}$

1.04

1.97

25-34 years

$1.27^{\star}$

1.05

1.54

35-49 years

0.94

0.81

1.11

50 or more (refer- $\quad 1.00$

ence)

\section{Has radio}

No

$$
1.50^{\star * *}
$$

Yes(reference)

1.00

\section{Has television}

No

$0.65^{\star * *}$

0.54

0.77

Yes (reference)

1.00

Source of drinking water

Protected source $\quad 1.00$

(reference)

Unprotected source $\quad 1.25$

0.89

1.74

Any household member migrated in past 10 years

\begin{tabular}{|c|c|c|c|}
\hline No (reference) & 1.00 & & \\
\hline Yes & 0.91 & 0.79 & 1.04 \\
\hline Constant & $0.170^{\star * *}$ & & \\
\hline Cox \& Snell R Square & 0.282 & & \\
\hline -2 Log likelihood & 5543.6 & & \\
\hline
\end{tabular}

\section{Discussion}

This study assessed the factors responsible for not having toilets in the context of Nepal, where households that lack a toilet were measured on the basis of their geographical and socio-economic characteristics. Socio-economic and demographic factors are found to be associated with access to portable water and improved sanitation facilities [17]. Furthermore, findings from other studies support the findings of this study on income, household size and region, which are significant predictors for sanitation access
[18]. Our findings show that households in the Terai region are less likely to have toilets, which is similar to the findings of the study conducted by the Center Bureau of Statistics [14]. The same study also found that the houses with poor economic status are less likely to have toilets compared to wealthier households. Thus, construction and use of toilets is highly associated with economic status(16). The literature shows that the construction of a toilet is linked with urbanization, which is similar in our study as well, where, the proportion of households having a toilet in an urban area is double to that in rural areas [19]. A study conducted in Myagdi district, three years after it was declared ODF, shows that almost all households had a storage of water facility $(98.8 \%)$ and hand washing basin near the latrine (99.2\%) [15]. Whereas, our study shows that only four out of five households have a fixed place for handwashing. Studies show that the unavailability of water facilities at toilets motivates people for open defecation and disuse of toilets [20]. Similarly, use of unprotected water for drinking is considered a major factor for diarrheal disease(21). Furthermore, mass media like television, radio, print media, internet, etc. play a significant role in spreading information and raising awareness on sanitation issues [13]. They can help trigger positive changes in public opinion and behavior on matters of public health concern. However, this is in contradicts with our findings, where, households having a radio are less like to have toilets in their houses. This study has a number of strengths and some limitations in the interpretation of the results. We used a nationally representative data set that was based on a validated questionnaire and methodology. The findings can be generalized to the whole country as this survey was nationally representative. We still have some limitations that need to be taken into account when interpreting our findings from this study. Because of the survey's cross-sectional design, all of the factors analyzed in the study were measured at a single point of time. Thus, the analysis can only provide evidence of statistical association between those items and the lack of a toilet in the household at that time; it cannot show a cause-effect relationship. However, the findings of this study will be helpful for program implementers and policy makers in suggesting 'what' needs to be focused 'where', in order to develop effective ODF related programs. Furthermore, our study reflected that socio-economic status of the people is associated with the availability of toilets in their house. However, having a toilet in a house does not mean that people are using toilets, as there are cultural, political, and behavioral factors affecting not just the availability but also their utilization.

\section{Conclusion}

Despite some real achievements and progress in trying to achieve ODF status in Nepal, there are still residences without access to adequate sanitation and toilet facilities. Province number two and the Terai region in particular need to be focused on for designing ODF programs to meet national and international sanitation goals.
Abbreviations
aOR: Adjusted odds ratio
BSP: Basic sanitation package
CI: Confidence interval
EA: Enumeration Area 
LMIC: Low - income and middle- income countries NDHS: Nepal Demographic and Health Survey NPC: National Population and Housing Census NSW: National Sanitation Week

OD: Open defecation

ODF: Open defecation free

PSU: Primary Sampling Units

Ref: Reference

SPSS: Statistical Package for Social Science

WASH: Nepal Water Sanitation and Hygiene

\section{Declarations}

\section{Ethical approval and consent to participate}

The study protocol was approved by the Nepal Health Research Council and the ICF Macro Institutional Review Board in Calverton, Maryland, USA. All respondents had provided verbal informed consent to be interviewed prior to data collection. Therefore, an independent ethical approval was not required. For this study, we used publicly available data set from the measure DHS website

\section{Consent to publish}

Not applicable

\section{Availability of data and materials}

The data used are publicly available from the MEASURE DHS site.

\section{Competing interests}

The authors declare that they have no competing interests.

\section{Funding}

Not applicable

\section{Acknowledgments}

The author thanks MEASUREDHS+ for providing access to the data.

\section{References}

1. Galvin M. Talking shit: is cmmunity-led total sanitation a radical and revolutionary approach to sanitation? WIREs Water [Internet]. 2015;2(1):9-20. Available from: http://doi.wiley.com/10.1002/wat2.1055

2. United Nations W. The Millennium Development Goals Report 2015 [Internet]. 2015. Available from: /citations?view_op=view_citation\&continue=/ scholar\%3Fhl\%3Den\%26as_sdt\%3D0,26\%26scilib\%3D1\%26scioq\%3Dthe\%2Bmillennium\%2Bgoals\%2Breport\%2B2015\&citilm=1\&citation_for_view=xgbvHCQAAAAJ:LK8CI43ZvvMC\&hl=en\&scioq=the+millennium+goals+report+2015\&oi=p\%0Ahttp://ww

3. McMichael C. Toilet Talk: Eliminating open defecation and improved sanitation in Nepal. Med Anthropol Cross Cult Stud Heal Illn. 2017;9740(September):1-17.

4. Garn J V., Sclar GD, Freeman MC, Penakalapati G, Alexander KT, Brooks P,

et al. The impact of sanitation interventions on latrine coverage and latrine use: A systematic review and meta-analysis. Int J Hyg Environ Health [Internet]. 2017;220(2):329-40. Available from: http://dx.doi.org/10.1016/j.ijheh.2016.10.001 5. GON. Sanitation and hygiene master plan. Kathmandu; 2011[Internet]. https:// www.ircwash.org/resources/sanitation-and-hygiene-master-plan.

6. GON. Government of Nepal Sanitation and Hygiene Master Plan [Internet]. Kathmnadu; 2011. Available from: http://washinschoolsmapping.com/wengine/ wp-content/uploads/2015/10/Nepal-Government-Sanitation-and-Hygiene-Master-Plan.pdf
7. WaterAid. Community led total sanitation in Nepal getting us back on track. Nepal; 2006.

8. Adhikari K. School led total sanitation: Principles and practices. J water, Sanit Heal Environ. 2010;8(1):8-10.

9. RWSSPWN. Celebrating the 19th National Sanitation Week [Internet]. Kathmandu; 2018. Available from: https://www.rwsspwn.org.np/single-post/2018/10/30/Celebrating-the-19th-National-Sanitation-Week 10. Lohani G. Sludge management is post-ODF challenge [Internet]. New Spotlight Magazine; Available from: https://www.spotlightnepal.com/2018/09/22/ sludge-management-is-post-odf-challenge/

11. Vyas S, Spears D, Vyas S, Spears D. sanitation and religion in South Asia : What accounts for differences across countries? Sanitation and Religion in South Asia : What Accounts for Differences across Countries? J Dev Stud [Internet]. 2018;54(11):2119-35. Available from: https://doi.org/10.1080/00220388.2018.146 9742

12. Shrestha S, Ahamad T, Shrestha P. Sustainability of ODF in Nepal. In: Transformation towards sustainable and resilient WASH services: Proceedings of the 41st WEDC International Conference. Kenya: WEDC, Loughborough University; 2018. p. $0-6$.

13. Showkat N. Coverage of Sanitation Issues in India. SAGE. 2016;6(4).

14. Dahal KR, Adhikari B, Tamang J. Sanitation Coverage And Impact Of Open Defecation Free (ODF) zone with special reference to Nepal: A Review. Int J Eng Res Appl [Internet]. 2014;4(8):118-28. Available from: http://www.ijera.com/ papers/Vol4_issue8/Version 7/R4807118128.pdf

15. Rajalakshmi S. Assessing the sanitary status in rural area. Int J Appl Home Sci [Internet]. 2017;4(9 \&10):677-85. Available from: http://scientificresearchjournal. com/wp-content/uploads/2017/08/Home-Science-Vol-4_A-677-685-Full-Paper. pdf

16. Kumari B, Magar P, Kaphle HP, Gupta N. Open Defecation Free ( ODF ) Status of Magdi district of Nepal after three years of declaration : A cross-sectional study. Int J Heal Sci Res. 2016;6(September):351-5.

17. Adams EA, Boateng GO, Amoyaw JA. Socioeconomic and demographic predictors of potable water and sanitation access in Ghana. Soc Indic Res [Internet]. 2015;126(2):673-87. Available from: http://www.scopus.com/inward/record. url?eid=2-s2.0-84957841320\&partnerID=tZOtx3y1

18. Minh, Minh, Nguyen Viet Hung. Economic aspects of sanitation in eveloping countries. Environ Health Insights [Internet]. 2011;78(21):63. Available from: http://www.la-press.com/economic-aspects-of-sanitation-in-developing-countries-article-a2871

19. Carthy J. Why poop is a big problem in india's cities \&rural areas alike [Internet]. global Citizen; 2016. Available from: https://www.globalcitizen.org/en/ content/urban-rural-two-sides-of-indias-sanitation-problem/

20. Novotný J, Hasman J, Lepič M. Contextual factors and motivations affecting rural community sanitation in low- and middle-income countries: A systematic review. Int J Hyg Environ Health. 2018;221(2):121-33.

21. Budhathoki SS, Shrestha G, Bhattachan M, Singh SB, Jha N, Pokharel PK. Latrine coverage and its utilisation in a rural village of Eastern Nepal: a community-based cross-sectional study. BMC Res Notes [Internet]. 2017;10(1):209. Available from: http://bmcresnotes.biomedcentral.com/articles/10.1186/s13104017-2539-3 